\title{
Investor protection and corporate governance
}

\section{Citation}

La Porta, Rafael, Florencio Lopez-de-Silanes, Andrei Shleifer, and Robert Vishny. 2000. “Investor Protection and Corporate Governance." Journal of Financial Economics 58 (1-2) (January): 3-27. doi:10.1016/s0304-405x(00)00065-9.

\section{Published Version}

doi:10.1016/S0304-405X(00)00065-9

\section{Permanent link}

http://nrs.harvard.edu/urn-3:HUL.InstRepos:29408126

\section{Terms of Use}

This article was downloaded from Harvard University's DASH repository, and is made available under the terms and conditions applicable to Other Posted Material, as set forth at http:// nrs.harvard.edu/urn-3:HUL.InstRepos:dash.current.terms-of-use\#LAA

\section{Share Your Story}

The Harvard community has made this article openly available.

Please share how this access benefits you. Submit a story.

Accessibility 


\title{
NBER WORKING PAPER SERIES
}

\section{INVESTOR PROTECTION: ORIGINS, CONSEQUENCES, REFORM}

\author{
Rafael La Porta \\ Florencio Lopez-de-Silanes \\ Andrei Shleifer \\ Robert Vishny \\ Working Paper 7428 \\ http://www.nber.org/papers/w7428
}

\author{
NATIONAL BUREAU OF ECONOMIC RESEARCH \\ 1050 Massachusetts Avenue \\ Cambridge, MA 02138 \\ December 1999
}

We are grateful to Nicholas Barberis, Simeon Djankov, Oliver Hart, Michael Jensen, Simon Johnson, Ross Levine, and Daniel Wolfenzon for helpful comments, and to the NSF for financial support of this research. The views expressed herein are those of the authors and not necessarily those of the National Bureau of Economic Research.

(C) 1999 by Rafael La Porta, Florencio Lopez-de-Silanes, Andrei Shleifer, and Robert Vishny. All rights reserved. Short sections of text, not to exceed two paragraphs, may be quoted without explicit permission provided that full credit, including (C) notice, is given to the source. 
Investor Protection: Origins, Consequences, Reform

Rafael La Porta, Florencio Lopez-de-Silanes, Andrei Shleifer, and Robert Vishny

NBER Working Paper No. 7428

December 1999

JEL No.G21, G28, G32

\begin{abstract}
Recent research has documented large differences between countries in ownership concentration in publicly traded firms, in the breadth and depth of capital markets, in dividend policies, and in the access of firms to external finance. We suggest that there is a common element to the explanations of these differences, namely how well investors, both shareholders and creditors, are protected by law from expropriation by the managers and controlling shareholders of firms. We describe the differences in laws and the effectiveness of their enforcement across countries, discuss the possible origins of these differences, summarize their consequences, and assess potential strategies of corporate governance reform. We argue that the legal approach is a more fruitful way to understand corporate governance and its reform than the conventional distinction between bank-centered and market-centered financial systems.
\end{abstract}

Rafael La Porta

Department of Economics

Harvard University

Cambridge, MA 02138

and NBER

Andrei Shleifer

Department of Economics

Littauer M9

Harvard University

Cambridge, MA 02138

and NBER

ashleifer@harvard.edu
Florencio Lopez-de-Silanes

Kennedy School of Government

Harvard University

79 JFK Street

Cambridge, MA 02138

and NBER

f_lopezdesilanes@harvard.edu

Robert W. Vishny

Graduate School of Business

The University of Chicago

1101 E. $58^{\text {th }}$ Street

Chicago, IL 60637

and NBER

vishny@gsb.uchicago.edu 


\section{Introduction.}

Recent research on corporate governance around the world has established a number of empirical regularities. Such diverse elements of countries' financial systems as the breadth and depth of their capital markets, the pace of new security issues, corporate ownership structures, dividend policies, and the efficiency of investment allocation appear to be explained both conceptually and empirically by how well the laws in these countries protect outside investors. According to this research, the protection of shareholders and creditors by the legal system is central to understanding the patterns of corporate finance in different countries.

Investor protection turns out to be crucial because, in many countries, expropriation of minority shareholders and creditors by the controlling shareholders is extensive. When outside investors finance firms, they face a risk, and sometimes near certainty, that the returns on their investments will never materialize because the controlling shareholders or managers simply keep them. (We refer to both managers and controlling shareholders as "the insiders".) Corporate governance is, to a large extent, a set of mechanisms through which outside investors protect themselves against expropriation by the insiders. Expropriation can take a variety of forms. In some countries, the insiders simply steal the profits. In other countries, the insiders sell the output or the assets of the firm they control, but which outside investors have financed, to another entity they own at below market prices. Such transfer pricing and asset stripping, though often legal, have largely the same effect as theft. In still other instances, perfectly legal expropriation takes the form of installing possibly unqualified family members in managerial positions, or overpaying executives. In general, expropriation is related to the agency problem described by Jensen and Meckling (1976), who focus on the consumption of “perquisites” by managers from the firm's 
profits. It means that the insiders use the profits of the firm to benefit themselves rather than return the money to the outside investors.

If extensive expropriation undermines the functioning of a financial system, how can it be limited? The legal approach to corporate governance holds that the key mechanism is the protection of outside investors-whether shareholders or creditors-through the legal system, meaning both laws and their enforcement. Although reputations or bubbles can help raise funds, law and its enforcement are central to understanding why firms raise more funds in some countries than in others. To a large extent, potential shareholders and creditors finance firms because their rights are protected by the law. These outside investors are more vulnerable to expropriation, and more dependent on the law, than either the employees or the suppliers, who remain continually useful to the firm and hence are at a lesser risk of being mistreated.

The legal approach to corporate governance is a natural continuation of the field as it developed over the last 40 years. Modigliani and Miller (1958) think of firms as collections of investment projects and the cash flows these projects create, and hence naturally interpret securities, such as debt and equity, as claims to these cash flows. They do not explain why the managers would return the cash flows to investors. Jensen and Meckling (1976) point out that the return of the cash flows from projects to investors cannot be taken for granted, and that the insiders of firms may use these resources to their own advantage. Jensen and Meckling view financial claims as contracts that give outside investors, such as shareholders and creditors, claims to the cash flows. In their model, the limitation on expropriation is the residual equity ownership by entrepreneurs that enhances their interest in dividends relative to perquisites.

Research by Grossman, Hart and Moore, summarized in Hart (1995), makes a further key 
advance by focusing squarely on investor power relative to the insiders, and distinguishing between the contractual and the residual control rights that investors have. Economists have used this idea to model financial instruments not in terms of their cash flows, but in terms of the rights they allocate to their holders. In this framework, investors get cash only because they have power. This may be the power to change directors, to force dividend payments, to stop a project or a scheme that benefits the insiders at the expense of outside investors, to sue directors and get compensation, or to liquidate the firm and receive the proceeds. Unlike in the Modigliani-Miller world, changing the capital structure of the firm changes the allocation of power between the insiders and the outside investors, and thus almost surely changes the firm's investment policy.

In both the contractual framework of Jensen and Meckling, and the residual control rights framework of Grossman, Hart and Moore, the rights of the investors are protected, and sometimes even specified, by the legal system. For example, contract law deals with privately negotiated arrangements, whereas company, bankruptcy, and securities laws specifically describe some of the rights of corporate insiders and outside investors. These laws, and the quality of their enforcement by the regulators and courts, are essential elements of corporate governance and finance (La Porta, Lopez-de-Silanes, Shleifer and Vishny LLSV 1997, 1998). When investor rights — such as the voting rights of the shareholders and the reorganization and liquidation rights of the creditors - are extensive and well enforced by regulators or courts, investors are willing to finance firms. When in contrast the legal system does not protect outside investors, corporate governance and external finance do not work well.

Jensen and Meckling (1976) recognize the importance of the legal system when they write: "This view of the firm points up the important role which the legal system and the law play 
in social organizations, especially, the organization of economic activity. Statutory law sets bounds on the kinds of contracts into which individuals and organizations may enter without risking criminal prosecution. The police powers of the state are available and used to enforce performance of contracts or to enforce the collection of damages for non-performance. The courts adjudicate contracts between contracting parties and establish precedents which form the body of common law. All of these government activities affect both the kinds of contracts executed and the extent to which contracting is relied upon (p. 311)."

One way to think about the legal approach is that legal protection of outside investors makes the expropriation technology less efficient. At the extreme of no investor protection, the insiders can steal a firm's profits perfectly efficiently. Without a strong reputation, no rational outsider would finance such a firm. As investor protection improves, the insiders must engage in more distorted and wasteful diversion practices, such as setting up intermediary companies into which they channel profits. Yet these mechanisms are still efficient enough for them to choose to divert a lot. When investor protection is very good, the most the insiders can do is overpay themselves, put relatives in management, and undertake some wasteful projects. After a point, it may be better just to pay dividends. As the diversion technology becomes less efficient, the insiders expropriate less, and their private benefits of control diminish. Firms then obtain outside finance on better terms. By shaping the expropriation technology, the law also shapes the opportunities for external finance.

The legal approach to corporate governance has emerged as a fruitful way to think about a number of questions in finance. In section 2, we discuss the differences in legal investor protection among countries, and the possible judicial, political, and historical origins of these differences. In 
section 3, we summarize the research on the economic consequences of investor protection. In section 4, we compare the legal approach to the more standard approach to comparative corporate governance, which focuses on the relative importance of banks and stock markets to explain country differences. In section 5, we discuss both the difficulties and the opportunities for corporate governance reform. Section 6 concludes.

\section{Investor Protection.}

When investors finance firms, they typically obtain certain rights or powers. Creditors get the right to repossess collateral or to reorganize the firm that does not pay interest or that violates debt covenants. Shareholders get the right to vote on key corporate matters, to select directors, or to sue the directors and the firm. All outside investors, whether shareholders or creditors, also have the right to receive certain corporate information. Indeed, many other rights can only be exercised when they have such information. For example, without accounting data, a creditor cannot know whether a debt covenant had been violated. Absent these rights, the insiders do not have much of a reason to repay the creditors or to distribute profits to shareholders.

All non-controlling investors-large or small, shareholders or creditors—-need their rights protected. Minority shareholders require the right to be treated in the same way as the more influential shareholders in dividend policies and in access to new security issues by the firm. The significant but non-controlling shareholders need the right to have their votes counted and respected. Even the large creditors-investors typically viewed as so powerful that they need relatively few formal rights — must be able to seize and liquidate collateral, or to reorganize the firm. Without an ability to enforce their rights, investors are likely to end up with nothing even if 
they hold claims to a significant fraction of the firm's capital.

Outside investors' rights are generally protected through the enforcement of regulations and laws. Some of the crucial regulations promulgated by government agencies or stock exchanges are disclosure and accounting rules, which provide investors with the information they need to exercise other rights. Protected shareholder rights include those to receive dividends on pro-rata terms, to vote for directors, to participate in shareholders' meetings, to subscribe to new issues of securities on the same terms as the insiders, to sue directors or the majority for suspected expropriation, to call extraordinary shareholders' meetings, and so on. Laws protecting creditors largely deal with bankruptcy and reorganization procedures, and include measures that enable creditors to repossess collateral, to protect their seniority, and to make it harder for firms to seek court protection in reorganization. In different jurisdictions, rules protecting investors come from different sources, including company, security, bankruptcy, takeover, and competition laws, but also stock exchange regulations and accounting standards. Enforcement of laws is as crucial as their content. In most countries, laws and regulations are enforced in part by market regulators, in part by courts, and in part by market participants themselves.

The emphasis on legal rules and regulations protecting outside investors stands in sharp contrast to the traditional "law and economics" perspective on financial contracting. According to this perspective, most regulations of financial markets are unnecessary, because financial contracts take place between sophisticated issuers and sophisticated investors. On average, investors recognize a risk of expropriation, and penalize firms that fail to contractually disclose information about themselves and to contractually bind themselves to treat investors well. Because entrepreneurs bear these costs when they issue securities, they have an incentive to bind 
themselves through contracts with investors to limit expropriation (Jensen and Meckling 1976). As long as these contracts are enforced, financial markets do not require regulation (Stigler 1964, Easterbrook and Fischel 1991).

Note that even this perspective, originating in the Coase (1961) theorem, relies on courts enforcing elaborate contracts, which in most countries cannot be taken for granted. Indeed, courts are often unable or unwilling to resolve complicated disputes, and are slow, subject to political pressures, and even corrupt. When the enforcement of private contracts through the court system is sufficiently costly, Coase himself clearly recognizes the possibility that other forms of protecting property rights, such as judicially-enforced laws or even government-enforced regulations, are more efficient. Given the ambiguity of the theory, the answer to whether contracts, courtenforced legal rules, or government-enforced regulations are the most efficient form of protecting financial arrangements is largely empirical. As the next section of this paper shows, the empirical evidence rejects the hypothesis that private contracting is sufficient. Even among countries with reasonably well functioning judiciaries, those with laws and regulations more protective of investors have better developed capital markets.

LLSV (1998) discuss a set of key legal rules protecting shareholders and creditors, and document their prevalence in 49 countries around the world. They also aggregate these rules into shareholder and creditor rights indices for each country, and consider several measures of enforcement quality, such as the efficiency of the judicial system, an index of corruption, and a measure of the quality of accounting standards. LLSV use these data to examine the variation of legal rules and enforcement quality across countries, and in particular across groups of countries whose laws derive from the same legal family. Their results are summarized in Table 1. 
Commercial legal systems of most countries derive from relatively few legal "families" (David and Brierley 1985). Some countries, such as England, Germany, and France, developed their own legal systems, the latter two based on Roman Law. In the 19th century, these systems spread throughout the world through conquest, colonization, and voluntary adoption. England and its former colonies, including the U.S., Canada, Australia, and New Zealand, but also many countries in Africa and South East Asia, have ended up with the common law system. France, Spain, the former French and Spanish colonies (including all countries in Latin America), as well as many countries Napoleon conquered, are part of the French or Napoleonic civil law tradition. Germany, Germanic countries in Europe, and a number of countries in East Asia are part of the German civil law tradition. The Scandinavian countries form their own legal tradition. The socialist countries had a legal tradition based on Soviet law, but because the laws of these countries are changing rapidly during transition out of socialism, LLSV do not consider them.

Table 1 presents the percentage of countries in each legal family scoring well on a number of indicators of investor rights, as well as the mean for that family antidirector and creditor rights scores. How well legal rules protect outside investors varies systematically across legal origins. Common law countries have the strongest protection of outside investors — both shareholders and creditors-whereas French civil law countries have the weakest protection. German civil law countries are in between, although comparatively speaking they have stronger protection of creditors, especially secured creditors. Scandinavian origin countries are similar to the German ones. In general, differences between legal origins are best described by the proposition that some countries protect all outside investors better than others, and not by the proposition that some countries protect shareholders and the others protect creditors. 
There are significant differences between countries in the quality of enforcement as well. The quality of enforcement also has several elements, from the efficiency of the judiciary to the quality of accounting standards. Unlike legal rules themselves, which do not appear to depend on the level of economic development, the quality of enforcement is higher in richer countries. In particularly, the -- generally richer -- Scandinavian and German legal origin countries, receive the best scores on corruption and the efficiency of the judicial system. The French legal origin countries have the worst quality of law enforcement of the four legal traditions, and this result holds even controlling for per capita income.

Because legal origins are highly correlated with the content of the law, and because legal families originated much before the financial markets have developed, it is unlikely that laws were written primarily in response to market pressures. Rather, the legal families appear to shape the legal rules, which in turn influence financial markets. But what is special about legal families? Why, in particular, is common law more protective of investors than civil law? These questions do not have an agreed upon answer. It may be useful to distinguish between two broad kinds of answers: the "judicial" explanations that account for the differences in the legal philosophies using the organization of the legal system, and the "political" explanations that account for the differences using political history.

The "judicial" explanation of why common law protects investors better runs as follows. ${ }^{2}$ Legal rules in the common law system are usually made by judges, based on precedents and inspired by general principles, such as fiduciary duty. Judges are expected to rule on new

${ }^{2}$ This explanation is consistent with David and Brierley (1985), and was most clearly articulated by John C. Coffee, Jr., during an August 1999 meeting at the NBER. 
situations by applying these general principles even when specific conduct has not yet been described or prohibited in the statutes. In the area of investor expropriation, the judges then apply what Coffee calls a "smell test," and try to sniff out whether even unprecedented conduct by the insiders violates their fiduciary duty. The expansion of legal precedents to additional violations of fiduciary duty, and the fear of such expansion, limits the expropriation by the insiders in common law countries. In contrast, legal rules in civil law systems are made by legislatures, and judges are not supposed to go beyond the exact letter of the law. No "smell tests" are allowed. As a consequence, a corporate insider who finds a way to expropriate outside investors which is not explicitly forbidden by the law, can proceed without fear of an adverse judicial ruling. From this perspective, the vague fiduciary duty principles of the common law are more protective of investors than the bright line rules of the civil law, which can often be circumvented by sufficiently imaginative insiders.

The judicial perspective on the differences is fascinating and possibly correct, but it is incomplete. It requires a further assumption that the judges have an inclination to protect the outside investors rather than the insiders. In principle, it is easy to imagine that the judges would use their discretion in common law countries to narrow the interpretation of fiduciary duty, and to sanction expropriation rather than prohibit it. Common law judges could also in principle use their discretion to serve political interests, especially when the outside investors obstruct the government's goals. To explain investor protection, it is not enough to focus on judicial power; a political and historical analysis of judicial objectives is required. From this perspective, important political and historical differences between mother countries shape their laws. This is not to say that laws never change (in section 5 we focus specifically on legal reform) but rather to suggest 
that history has persistent effects. How so?

LLSV (1999a) argue that an important historical factor shaping laws is the relatively greater role of the state in regulating business in civil than in common law countries. One element of this view, suggested by Finer (1997) and other historians, points to the differences in the relative power of the king and the property owners across European states. In England from the seventeenth century on (and arguably before), the crown partially lost control of the courts, which came under the influence of the parliament and the property owners who dominated it. As a consequence, common law evolved to protect private property against the crown. Over time, courts extended such protection of property owners to investors. In France and Germany, by contrast, the parliaments never dominated the kings, and the state dominated the courts and the property owners. Commercial Codes were adopted only in the nineteenth century by the two great state builders, Napoleon and Bismarck, to enable the state to better regulate economic activity. As the law evolved, the dominance of the state translated into the more political conception of the corporation, and the more limited rights of investors in dealing with the politically connected families that control firms. After all, the state was not about to surrender its power over business to the financiers ${ }^{3}$. Relatedly, courts in civil law countries, unlike those in England, were more dependent on the government, and less likely to take the side of investors in disputes with the government or with the firms that were close to it. As a consequence of these divergent political histories, common law developed to become more protective of investors than did civil law.

${ }^{3}$ According to Cameron (1961), France had a lively stock market in the nineteenth century. Nearly all firms listed on it, however, benefitted from government concessions, investment, ownership, subsidies, protection, and often outright guarantees to investors. 
Recent research supports the proposition that civil law is associated with greater government interference in economic activity, and weaker protection of private property. LLSV (1999a) examine the determinants of government performance in a large number of countries. To measure government interventionism, they consider proxies for the quality of regulation, the prevalence of corruption and of red tape, and bureaucratic delays. They find that, as a general rule, civil law countries, and particularly French civil law countries, are more interventionist than common law countries. The inferior protection of the rights of outside investors in civil law countries may be one manifestation of this general phenomenon. This evidence thus provides some support for interpreting the differences in legal families in light of political history.

Berglof and von Thadden (1999) and Rajan and Zingales (1999), while agreeing with our view that political history accounts for the differences in legal systems and corporate governance regimes among countries, question our emphasis on the legal protection of outside investors. According to Berglof and von Thadden (1999) countries may develop other mechanisms for stopping expropriation, such as moral sanctions or worker participation in management. Rajan and Zingales (1999) maintain that legal rules are not sufficiently durable to protect investors from the state determined to change corporate control, and that the political structure rather than the specific legal rules explains differences in investor protection. These interpretations of legal regimes as reflecting broader political sentiments in a society are consistent with our own position (LLSV 1999a). At the same time, investor protection may still be a key route through which longrun political sentiment, as reflected by the legal family, influences financial markets. In the next section, we describe some empirical research consistent with this proposition. 


\section{Consequences of Investor Protection}

Three broad areas in which investor protection has been shown to matter are the ownership patterns of firms, the development of financial markets, dividend policies, and the allocation of real resources.

\section{Patterns of Ownership and Control}

The focus on expropriation of investors and its prevention has a number of implications for the ownership structures of firms. Consider first the concentration of control rights in firms (as opposed to the dividend or cash flow rights). At the most basic level, when investor rights are poorly protected and expropriation is feasible on a substantial scale, control acquires enormous value because it gives the insiders the opportunity to expropriate relatively efficiently. If the insiders actually do expropriate, the so-called private benefits of control become a substantial share of the firm value. This observation raises a question: will control in such an environment be concentrated in the hands of an entrepreneur, or dispersed among many investors?

The research in this area originates in the work of Grossman and Hart (1988) and Harris and Raviv (1988), who examine the optimal allocation of voting and cash flow rights in a firm. The specific question of how control is likely to be allocated has not received an unambiguous answer. On the one hand, entrepreneurs who start companies may not want to give up control by diffusing control rights when investor protection is poor. Perhaps most obviously, to the extent that significant expropriation of outside investors requires secrecy, sharing control with other shareholders may interfere with expropriation (La Porta, Lopez-de-Silanes, and Shleifer, LLS 1999). When investor protection is poor, the dominant shareholder may find it more profitable to 
keep complete control. In addition, Zingales (1995), LLS (1999) and Bebchuk (1999) argue that if entrepreneurs disperse control between many investors, they give up the "private benefits" premium in the event of a takeover. In Bebchuk's (1999) model, diffuse control structures are unstable when investors can concentrate control without fully paying for it. Finally, an entrepreneur or his family may need to retain control of the firm because the family's reputation is needed to raise external funds when the legal protection of outside investors is poor. For all these reasons, firms in countries with poor investor protection may need concentrated control.

Bennedsen and Wolfenzon (2000) make a countervailing argument. When investor protection is poor, dissipating control among several large investors-none of whom can control the decisions of the firm without agreeing with the others-may serve as a commitment to limit expropriation. When there is no single controlling shareholder, and the agreement of several large investors (the board) is needed for major corporate actions, these investors might together hold enough cash flow rights to choose to limit expropriation of the remaining shareholders and pay the profits out as efficient dividends. When the dissipation of control reduces inefficient expropriation, it may emerge as an optimal policy for a wealth-maximizing entrepreneur.

If entrepreneurs choose to retain control over the firm, they have a number of ways of doing so. They can sell shares with limited voting rights to the outsiders, and retain control by holding on to the shares with superior voting rights. They can use a pyramidal structure, in which a holding company controlled by the entrepreneurs issues shares in a subsidiary that it itself controls. The entrepreneurs can then control the subsidiary without owning a substantial fraction of its cash flow rights (Wolfenzon 1999). Entrepreneurs can also keep control by using crossshareholdings between a group of firms, making it harder for outsiders to gain control of any one 
firm without gaining control of all of them.

What about the distribution of cash flow rights, as opposed to control, between investors? If entrepreneurs retain control of a firm, how can they raise any external funds from outside investors - for financing or for diversification — who expect to be expropriated? The reasoning of Jensen and Meckling would suggest that cash flow ownership by entrepreneurs would reduce incentives for expropriation and would increase incentives to pay out dividends. Such a need for higher cash flow ownership as a commitment to limit expropriation may be higher in countries with inferior shareholder protection (LLSV 1999b).

The available evidence on corporate ownership patterns around the world supports the importance of investor protection. This evidence was obtained for a number of individual countries, including Germany (Edwards and Fischer 1994, Gorton and Schmid 1999), Italy (Barca 1995), and seven Organization for Economic Co-operation and Development countries (European Corporate Governance Network 1997). LLSV (1998) describe ownership concentration in their sample of 49 countries, while LLS (1999) examine patterns of control in the largest firms from each of 27 wealthy economies. The data show clearly that countries with poor investor protection typically exhibit more concentrated control of firms than do countries with good investor protection. In the former countries, even the largest firms are usually controlled either by the families that founded or acquired these firms or by the state. In the latter countries, the Berle and Means corporation — with dispersed shareholders and professional managers in control—is more common $^{4}$.

\footnotetext{
${ }^{4}$ The evidence also shows directly that control is valued, and specifically that voting premiums increase as shareholder protection deteriorates (see, for example, Modigliani and Perotti 1998, Nenova 1999, and Zingales 1994).
} 
Claessens, Djankov and Lang (1999) examine a sample of nearly 3,000 firms from 9 East Asian economies. Except in Japan, which has fairly good shareholder protection, they find a predominance of family control and family management of the corporations in their sample, with some state control as well. They also present remarkable evidence of "crony capitalism" in Asia: outside Japan, the top 10 families in each of the remaining 8 countries they study control between 18 and 58 percent of the aggregate value of listed equities.

In sum, the evidence has proved to be broadly consistent with the proposition that the legal environment shapes the value of the private benefits of control, and therefore determines the equilibrium ownership structures. Perhaps the main implication of this evidence for the study of corporate governance is the relative irrelevance of the Berle and Means corporation in most countries in the world, and the centrality of family control. Indeed, LLS (1999) and Claessens, Djankov and Lang (1999) find that family-controlled firms are typically managed by family members, so that the professional managers appear to be kept on a tighter leash than what Berle and Means describe. In large corporations of most countries, the fundamental agency problem is not the Berle and Means conflict between outside investors and managers, but rather that between outside investors and controlling shareholders, who in particular have nearly full control over the managers (Shleifer and Vishny 1997).

\section{Financial Markets}

The most basic prediction of the legal approach is that investor protection encourages the development of financial markets. When investors are protected from expropriation, they pay more for securities, making it more attractive for entrepreneurs to issue these securities. This 
applies to both creditors and shareholders. Creditor rights encourage the development of lending, and the exact structure of these rights may alternatively favor bank lending or market lending. Shareholder rights encourage the development of equity markets, as measured by the valuation of firms, the number of listed firms (market breadth), and the rate at which firms go public. For both shareholders and creditors, protection includes not only the rights written into the laws and regulations, but also the effectiveness of their enforcement. Consistent with these predictions, LLSV (1997) show that countries that protect shareholders have more valuable stock markets, larger numbers of listed securities per capita, and a higher rate of IPO (initial public offering) activity than do the unprotective countries. Countries that protect creditors better have larger credit markets.

Several recent studies have also established a link between investor protection, insider ownership of cash flows, and corporate valuation ${ }^{5}$. Gorton and Schmid (1999) show that higher ownership by the large shareholders is associated with higher valuation of corporate assets in Germany. Claessens, Djankov, Fan and Lang (1999), using a sample of East Asian firms, show that greater insider cash flow ownership is associated with higher, and greater insider control of voting rights with lower, valuation of corporate assets. Using a sample of firms from 27 wealthy economies, LLSV (1999b) find that, other things equal, firms in countries with better shareholder protection have higher Tobin's $Q$ than do firms in countries with inferior protection. They also find that higher insider cash flow ownership is (weakly) associated with higher corporate valuation, and that this effect is greater in countries with inferior shareholder protection. These

${ }^{5}$ In addition, LLSV (2000) show that better minority shareholder protection is associated with higher dividend pay-outs in a cross-section of firms from around the world. 
results are consistent with the importance of investor protection and of cash flow ownership by the insiders in limiting expropriation (Jensen-Meckling 1976).

Johnson and others (1999) draw an ingenious connection between investor protection and financial crises. In countries with poor protection, the insiders might treat outside investors well as long as future prospects are good and they are interested in continued external financing. When future prospects deteriorate, however, the insiders step up expropriation, and the outside investors - whether shareholders or creditors - are unable to do anything about it. This escalation of expropriation renders security price declines in countries with poor investor protection especially deep. To test this hypothesis, Johnson and others (1999) examine the depreciation of currencies and the decline of the stock markets in 25 countries during the Asian crisis of 19971998. They find that governance variables, such as investor protection indices and the quality of law enforcement, are powerful predictors of the extent of market declines during the crisis. These variables explain the cross-section of declines better than do the macroeconomic variables which have been the focus of the policy debate.

\section{Real Consequences}

Through its effect on financial markets, investor protection influences the real economy. Financial development can accelerate economic growth in three ways (Beck, Levine, and Loayza 2000). First, it can enhance savings. Second, it can channel these savings into real investment and thereby foster capital accumulation. Third, to the extent that the financiers exercise some control over the investment decisions of the entrepreneurs, financial development improves the efficiency of resource allocation, as capital flows toward the more productive uses. All three channels can in 
principle have large effects on economic growth.

A large literature links financial development to economic growth. King and Levine (1993) initiate the modern incarnation of this literature by showing that countries with larger initial capital markets grow faster in the future. Subsequent work by Demirguc-Kunt and Maksimovic (1998), Levine and Zervos (1998), Rajan and Zingales (1998), and Carlin and Mayer (1999) extends these findings. Several of these papers show that an exogenous component of financial market development, obtained by using legal origin as an instrument, predicts economic growth.

More recent research distinguishes the three channels through which finance can contribute to growth: saving, factor accumulation, and efficiency improvements. Beck, Levine, and Loayza (2000) find that banking sector development exerts a large impact on total factor productivity growth, and a less obvious impact on private savings and capital accumulation. Moreover, this influence continues to hold when an exogenous component of banking sector development, obtained using legal origin as an instrument, is taken as a predictor. Wurgler (2000) finds that financially developed countries allocate investment across industries more in line with growth opportunities in these industries than do the financially undeveloped countries. Morck, Yeung, and Yu (2000) find that stock markets in more developed countries incorporate firmspecific information better, and so may help allocate investment more effectively. This research suggests that financial development improves resource allocation. Through this channel, investor protection may benefit the growth of productivity and output.

\section{Summary}


The research described in this section has a number of implications for the study of financial markets. First, it shows that the most developed financial markets are the ones in which investors are best protected from expropriation by the insiders. It does not tell us what the best form of such protection is, which may well include self-regulation and judicially enforced laws, as well as government regulation. Still, totally unregulated financial markets do not work well, presumably because they allow too much expropriation of outside investors by corporate insiders. One dramatic illustration of this phenomenon, stressed by Coffee (1999), is the fact that the most sought after place in the world for listing by publicly traded companies happens to be New York City - a heavily regulated exchange when it comes to disclosure and protection of minority shareholders_-rather than Mexico City.

Second, improving the functioning of financial markets has real benefits both in overall economic growth and in the allocation of resources across sectors. Finally, one broad strategy of effective regulation, and of encouragement of financial markets more generally, begins with protection of outside investors, whether they are shareholders or creditors.

This analysis raises important questions for reform. How can a policy maker try to improve markets? What reforms are good? We address these questions in section 5, but first examine an alternative approach to the study of corporate governance.

\section{Bank- and Market-Centered Governance}

Traditional comparisons of corporate governance systems focus on the institutions financing firms rather than on the legal protection of investors. Bank-centered corporate governance systems, such as those of Germany and Japan, are thus compared to market-centered 
systems, such as those of the United States and the United Kingdom (for example, Allen and Gale 1999). Relatedly, relationship-based corporate governance, in which a main bank provides a significant share of finance and governance to each firm, is contrasted with market-based governance, in which finance is provided by large numbers of investors and in which takeovers play a key governance role.

These institutional distinctions have been central to the evaluation of alternative corporate governance regimes, and to policy proposals for improvement. In the 1980s, when the Japanese economy could do no wrong, bank-centered governance was widely regarded as superior (Aoki and Patrick 1993). It enabled firms to focus on the long term in making investment decisions because main banks were far-sighted (Porter 1992). It delivered capital to firms facing liquidity shortfalls, thereby avoiding costly financial distress (Hoshi, Kashyap, and Scharfstein 1991). It replaced the expensive and disruptive takeovers with more surgical bank intervention when the management of the borrowing firm underperformed. In the 1990s, as the Japanese economy collapsed, the pendulum swung the other way $^{6}$. Far from being the promoters of rational investment, Japanese banks perpetrated soft budget constraints - over-lending to declining firms that required radical reorganization (Kang and Stulz 1998). Far from facilitating governance, these banks colluded with enterprise managers to deter external threats to their control and to collect rents on bank loans (Weinstein and Yafeh 1998, Morck and Nakamura 1999). German banks were likewise downgraded to ineffective providers of governance (Edwards and Fischer 1994, Hellwig 1999). Market-based systems, in contrast, rode the American stock market bubble of the 1990s into the stratosphere of wide support and adulation.

\footnotetext{
${ }^{6}$ Jensen (1989) expresses some early skepticism about the Japanese financial system.
} 
Unfortunately, the classification of financial systems into bank- and market-centered is neither straightforward nor particularly fruitful. To begin, one way to classify is by looking at the actual outcomes. It is easy to classify Germany as bank-centered, because it has powerful banks that influence firms through both debt and equity holdings and an underdeveloped stock market (although even in the case of Germany, Hellwig (1999) doubts that banks are so powerful). But what about Japan, which boasts both powerful banks with influence over firms and a highly developed and widely-held equity market (second or third in the world by size), with thousands of listed securities? Or what about the French-civil-law-based financial systems, in which neither credit markets nor stock markets are especially well developed? In Italy, for example, the stock market is extremely underdeveloped, but so is the banking system, and a typical firms raises a small amount of money from each of a dozen banks (Sapienza 1999). More generally, LLSV (1997) show that, on average, countries with bigger stock markets also have higher ratio of private debt to GDP (gross domestic product), contrary to the view that debt and equity finance are substitutes. The prevalent financing modes generally do not help with the classification.

Another way to classify financial systems is based on the existence of Glass-Steagall regulations, which restrict bank ownership of corporate equity. This approach is again useful for distinguishing the United States, which has such regulations, from Germany, which does not. On the other hand, most countries in the world do not have Glass-Steagall regulations. Some of them, like the United Kingdom, have an highly developed stock market and few equity holdings by banks, even though banks are not prevented by law from holding equity. Other countries have neither a developed banking system nor a developed stock market. Glass-Steagall regulations in themselves do not assure a development of a market system by interfering with corporate 
governance by banks. Consistent with our skepticism about the usefulness of such regulations for classifying financial systems, LLS (1999) show that Glass-Steagall regulations have no predictive power for ownership concentration across countries.

Perhaps most important, the reliance on either the outcomes or the Glass-Steagall regulations to classify corporate governance regimes misses the crucial importance of investor rights. All financiers depend on legal protection to function. A method of financing develops when it is protected by the law that gives financiers the power to get their money back. Germany and some other German civil law countries have a well-developed banking system because they have strong legal protection of creditors, particularly of secured creditors. Without such rights, German banks would have much less power. The United Kingdom also has a large banking and public debt sector, again because creditors have extensive rights, as well as a large equity market. Italy and Belgium, in contrast, have developed neither debt nor equity markets because no outside investors are protected there. ${ }^{7}$ The point here is simple: all outside investors-large or small, creditors or shareholders—need rights to get their money back. Investor rights are a more primitive determinant of financial market development than is the size of particular institutions.

Despite the difficulty of classifying financial systems into bank- and market-centered, economists at least since Gerschenkron (1962) have engaged in a lively debate as to which one is superior, focusing on the hypothesis that bank-centered systems are particularly suitable for developing economies. This is not a place to review this debate. Our concern is rather that the interest in monopoly bank lending distracts attention from the important role that stock markets

\footnotetext{
${ }^{7}$ More generally, Levine, Beck and Loayza (2000) find that the LLSV measure of creditor rights is correlated with measures of financial intermediaries development across countries, while the LLSV measure of shareholder rights is correlated with stock market development.
} 
play in external finance. Equity financing is essential for the expansion of new firms, whose main asset are the growth opportunities. In principle, firms could utilize private equity financing, but it has many of the same problems of excessive investor power suppressing entrepreneurial initiative as monopoly banking does (Myers 1977, Burkart, Gromb, and Panunzi 1997). Public equity financing, for which a developed stock market is needed, has other advantages over private equity financing. It allows the buyers of equity to diversify. It offers the initial equity holders, such as venture capitalists, an attractive exit option through the public equity markets. Last but not least, it allows firms to time their equity issues to take advantage of favorable investor sentiment toward their industry, or toward the market as a whole. Such sentiment may play a beneficial role when shareholders are skeptical about the likelihood of getting back a return on their money. Indeed, Keynes (1931) and others have argued that bubbles play an important and positive role in stimulating investment.

To summarize, bank- versus market-centeredness is not an especially useful way to distinguish financial systems. Investor rights work better to explain differences between countries, and in fact are often necessary for financial intermediaries to develop. Moreover, even if some countries go through monopoly-banking in their development process, this stage has little to recommend it other than as a stepping stone toward more developed markets. And to get to more developed markets, it is essential to improve the rights of outside investors.

\section{Possibilities for Reform}

In the last decade, the reform of corporate governance has attracted interest in Western and Eastern Europe, Latin America, and Asia. To discuss any reform, it is important to start with 
its goals. Our analysis suggests that the objective of corporate governance reform is to protect the rights of outside investors, including both shareholders and creditors. As the evidence shows, the benefits of such reform would be to expand financial markets, to facilitate external financing of new firms, to move away from concentrated ownership, and to improve the efficiency of investment allocation.

So what, if anything, can be done to achieve this goal, and what are the obstacles? To organize this discussion, we follow Coffee (1999) in drawing a distinction between legal and functional convergence. Legal convergence refers to the changes in the rules and in enforcement mechanisms toward some desirable standard. To achieve legal convergence to effective investor protection, most countries require extensive legal, regulatory, and judicial reform. Alternatively, functional convergence refers to more decentralized, market-based changes, which do not require legal reform per se, but still bring more firms and assets under the umbrella of effective legal protection of investors. We discuss these paths of reform in turn.

For most countries, the improvement of investor protection requires rather radical changes in the legal system. Securities, company, and bankruptcy laws generally need to be amended. The particular list of legal protections of investors studied by LLSV (1998) is neither necessary nor sufficient for such reforms. There may be significant complementarities between various laws in protecting minority shareholders: securities laws, for example, may mandate disclosure of material information while company laws enable minority shareholders to act on it. Moreover, the regulatory and judicial mechanisms of enforcing shareholders and creditor rights would need to be radically improved. In fact, the evidence on the importance of the historically determined legal origin in shaping investor rights—-which could be thought of as a proxy for the law's general 
stance toward outside investors — suggests at least tentatively that many rules need to be changed simultaneously to bring a country with poor investor protection up to best practice.

The political opposition to such change has proved intense. Governments are often reluctant to introduce laws that surrender to the financiers the regulatory control they currently have over large corporations. Important objections to reform also come from the families that control large corporations. From the point of view of these families, an improvement in the rights of outside investors is first and foremost a reduction in the value of control, as expropriation opportunities deteriorate. The total value of these firms may increase as a result of legal reform, as expropriation declines and investors finance new projects on more attractive terms; still, the first order effect on the insiders is a tax on them to benefit minority shareholders and creditors. No wonder, then, that in all countries_-from Latin America, to Asia, to Western and Eastern Europe-the families have opposed legal reform.

There is a further reason why the insiders in major firms oppose corporate governance reform and the expansion of capital markets. Under the status quo, the existing firms can finance their own investment projects internally (Mayer 1988) or through captive or closely connected banks. In fact, LLSV (1997) show that the lion's share of credit in countries with poor creditor protection goes to the few largest firms. As a consequence, the large firms obtain not only the finance they need, but also the political influence that comes with the access to such finance, as well as the protection from competition that would come if smaller firms could also raise external capital. When new entrepreneurs have good projects, they often have to come to the existing firms for capital. Poor corporate governance delivers the insiders not only secure finance, but also secure politics and markets. They have an interest in keeping the system as is. 
Consistent with the dominance of interest group politics, successful reforms have occurred only when the special interests could be destroyed or appeased. In this respect, corporate governance reform is no different from most other reforms in developing or industrial countries (Hirschman 1963, Shleifer and Treisman 1999). One example of significant legal reform of corporate governance is Japan after World War II, where General McArthur, assisted by attorneys from Chicago and an occupying army, introduced an Illinois-based company law (Ramseyer and Nakazato 1999). Another example is securities markets regulation in the United States in 1933-1934, immediately after Franklin Roosevelt's election and in the middle of the Great Depression. Although these regulations have been criticized (Stigler 1964), there is little doubt that they have substantially increased corporate disclosure in the United States. Still another example, where the success has been arguably more limited, is bankruptcy reform in East Asia following the crisis of 1997. These examples suggest that opportunities for corporate governance reform do arise, but under special circumstances. They should not be wasted.

Unfortunately, the opportunities have often been wasted because our understanding of the principles of reform of investor protection remains limited. There is no checklist of what needs to be done. We can, however, summarize some of the tentative principles of such reform that are emerging from recent research.

Perhaps the first such principle is that legal rules do matter. It is not just the stance of the law or the political sentiment that shapes financial markets. One illustration of this principle is the Neuer Markt in Germany, a segment of the Frankfurt Stock Exchange created especially for new firms wishing to go public (Johnson 1999). Because the Neuer Markt operates in Germany, the corporate law, the securities law, and other basic laws and regulations that are applied to the 
companies listed there are the general German rules. The politics are German as well. As part of a private contract with firms wishing to list on the Neuer Markt, the Deutsche Bourse -- which operates the Frankfurt Stock Exchange -- has mandated that these firms must comply with international accounting standards, and agree to more stringent disclosure requirements than those applicable to already listed firms. The new listing venue-with its greater restrictions on the entrepreneurs - has sharply accelerated the pace of initial public offerings in Germany. At the same time, the captains of German industry have accepted it because their firms have not been directly affected, pointing to one possible strategy of overcoming political opposition to reform.

A second principle is that the enforcement of legal rules is deeply integrated with the rules themselves. The strategy for reform is not to create an ideal set of rules and then see how they can be enforced, but rather to enact the rules that can be enforced with the existing enforcement structure. A famous example of the success of such a policy is the U.S. securities legislation of 1933-1934. The creator of these laws, James Landis, a former professor of administrative law, was keenly focused on enforcement (McCraw 1984). His strategy for forcing corporate disclosure was to demand independent audits of firms' accounts, and to make the accountants liable for their reports. Although the accounting firms initially resisted these reforms, they soon appreciated the increase in the demand for their services. The accounting profession became an independent and private force in assuring the compliance with disclosure regulations, with only limited government oversight. At the time at least, it would have been impossible for the government to enforce disclosure regulations on its own, without creating such incentives for private self-regulation. The principle of bringing private intermediaries into the enforcement of securities regulations has since been followed by a number of countries, including Germany and Poland (Johnson 1999, Johnson 
and Shleifer 1999).

The importance of enforcement is also illustrated by the difficulties with reforming bankruptcy procedures in East Asian countries and elsewhere. In general, improving bankruptcy procedures is harder than improving shareholder rights, because different types of creditors, unlike the different non-controlling shareholders, have different objectives. Senior creditors, especially the secured senior creditors, prefer rapid liquidation of bankrupt firms. Junior creditors and shareholders, whose claims are less secure, may prefer more orderly liquidation or even reorganization. These conflicts have assured that most countries have opted for rather slow, reorganization-focused bankruptcy schemes rather than liquidations (Hart 1999).

The trouble is, bankruptcy procedures almost inevitably rely on significant adjudication by the courts. Yet courts in many countries are reluctant to be too active in matters as political and complicated as closure or liquidation of companies. In the aftermath of the Asian crisis, several East Asian countries have tried to speed up bankruptcies. Yet relatively few cases, especially of large firms, have been sorted out so far, in part because courts are politicized and not ready to adopt accelerated procedures.

A third—and potentially more controversial—principle of successful reform is that government regulation of financial markets may be useful when court enforcement of private contracts or even of laws cannot be relied on (Johnson and Shleifer 1999). An example of how regulation can work when courts are far from perfect comes from the securities law reform in Poland and the Czech Republic, two transition economies whose judiciaries were generally viewed as ineffective. In the early 1990s, the Polish government introduced a tough securities law focused on shareholder protection. Like the U.S. securities law, the Polish regulations focused on 
significant disclosure by issuers and already listed firms, as well as on licensing and close administrative oversight of intermediaries. The law also provided for a creation of a powerful securities and exchange commission (SEC) with significant enforcement powers that did not require a reliance on courts. This reform was followed by a remarkable development of the Polish stock market, with both new and already listed companies raising equity in the market.

By contrast, the Czech government chose neither to introduce tough securities laws nor to create a powerful market regulator at the time of privatization. Perhaps as a consequence, the Czech markets have been plagued by massive expropriation of minority shareholders- the socalled "tunneling" of assets from both firms and mutual funds. In contrast to the Polish market, the Czech market stagnated, with hundreds of companies getting delisted and virtually no public equity financing by firms (see Coffee 1999, Pistor 1999, Johnson and Shleifer 1999). The comparison of Poland and the Czech Republic is an almost perfect experiment, because the two countries share roughly similar incomes, economic policies, and quality of judiciaries. In these circumstances, regulation of the stock market and listed firms in Poland, with its focus on investor protection, appeared to play a beneficial role.

The successful regulations of the U.S. securities markets, the Polish financial markets, and the Neuer Markt in Germany share a common element, namely the extensive and mandatory disclosure of financial information by the issuers, the accuracy of which is enforced by tightly regulated financial intermediaries. Although such disclosure is not sufficient by itself, without the right the shareholders to act on it, it appears to be a key element of shareholder protection. Although the legal reform has been slow and halting in most countries, "functional convergence" may play a role in improving investor protection. The liberalization of capital 
markets in many countries has increased not only the flow of foreign investment into them, as Henry (2000) and Stulz (1999) document, but also the economic and political pressure to create financial instruments acceptable to foreign investors. These pressures give rise to several forms of functional convergence. If contracts are enforced well, companies in unprotective legal regimes can offer their investors customized contracts, such as corporate charters, with greater rights than the law generally provides. This strategy relies on perhaps a greater enforcement capacity of investors and courts than is warranted, and ignores the empirically clear public good benefit of standard rules. A more promising approach is for companies to opt into the more investor friendly legal regimes. One way of doing this is to list a company's securities on an exchange that protects minority shareholders through disclosure or other means. This, in fact, is done by many companies that list their shares as American Depositary Receipts (ADRs) in New York. But such listing imposes only limited constraints on the insiders: although it improves disclosure, it typically does not give minority shareholders many effective rights.

A related mechanism of opting into a more protective legal regime is acquisition by a company already operating in such a regime. When a British company fully acquires a Greek company, the possibilities for legal expropriation of investors diminish. The controlling shareholders of the Greek company can be compensated in such a friendly deal for the lost private benefits of control, making them more likely to go along. By replacing the wasteful expropriation with publicly shared profits and dividends, such acquisitions enhance efficiency.

It is important to recognize the limitations of functional convergence, particularly in the area of creditor rights. Assets located in particular countries generally remain under the jurisdiction of these countries' laws. Without bankruptcy reform, opt-in mechanisms are unlikely 
to address the legal problems faced by domestic, and especially foreign, creditors. Despite the benefits of opting into the more protective legal regime for external finance, then, this mechanism is unlikely to fully replace bona fide legal reform.

\section{Conclusion}

This paper describes the legal protection of investors as a potentially useful way of thinking about corporate governance. Strong investor protection may be a particularly important manifestation of the greater security of property rights against political interference in some countries. Empirically, strong investor protection is associated with effective corporate governance, as reflected in valuable and broad financial markets, dispersed ownership of shares, and efficient allocation of capital across firms. Using investor protection as the starting point appears to be a more fruitful way to describe differences in corporate governance regimes across countries than some of the more customary classifications, such as bank- or market-centeredness.

An important implication of this approach is that leaving financial markets alone is not a good way to encourage them. Financial markets need some protection of outside investors —whether by courts, by government agencies, or by market participants themselves. Improving such protection is a difficult task. In part, the nature of investor protection, and of regulation of financial markets more generally, is deeply rooted in the legal structure of each country, and in the origin of its laws. Reform on the margin may not successfully achieve the reformer's goals. In part, the existing corporate governance arrangements benefit both the politicians and the entrenched economic interests, such as the families that manage the largest firms in most countries in the world. Corporate governance reform must circumvent the opposition by these interests. 
Despite these difficulties, investor protection reform can bring significant benefits, and is politically feasible in some circumstances. It can take the form of opting into more protective legal regimes, as well as of introducing more radical change in the legal structure. The integration of world capital markets makes such reforms more likely today than they have been in decades. 


\section{References}

Allen, Franklin, and Douglas Gale. 1999. Comparing Financial Systems. Cambridge, Mass: MIT Press.

Aoki, Masahiko and Hugh Patrick. 1993. The Japanese Main Bank System: Its Relevance for Developing and Transforming Economies. New York: Oxford University Press.

Barca, Fabrizio. 1995. “On Corporate Governance in Italy: Issues, Facts, and Agency.” Rome: Bank of Italy. Manuscript.

Bebchuk, Lucian. 1999. "The Rent Protection Theory of Corporate Ownership and Control." Cambridge, Mass: Harvard Law School. Manuscript.

Beck, Thorsten, Ross Levine, and Norman Loayza. 2000. "Finance and the Sources of Growth." Journal of Financial Economics.

Bennedsen, Morten, and Daniel Wolfenzon. 2000. “The Balance of Power in Close Corporations."Journal of Financial Economics.

Berglof, Eric, and Ernst-Ludwig von Thadden. 1999. "The Changing Corporate Governance Paradigm: Implications for Transition and Developing Countries.” Manuscript. Stockholm, Sweden: Stockholm Institute of Transition Economics.

Burkart, Mike, Denis Gromb, and Fausto Panunzi. 1997. "Large Shareholders, Monitoring, and Fiduciary Duty." Quarterly Journal of Economics 112, 693-728.

Cameron, Rondo E. 1961. France and the Economic Development of Europe. Princeton, NJ: Princeton University Press.

Carlin, Wendy, and Colin Mayer. 1999. "Finance, Investment and Growth.” London: University College. Manuscript. 
Claessens, Stijn, Simeon Djankov, and Larry H.P. Lang. 1999. “The Separation of Ownership and Control in East Asian Corporations.” Washington, DC: World Bank. Manuscript. Claessens, Stijn, Simeon Djankov, Joseph Fan, and Larry H.P. Lang. 1999. “Expropriation of Minority Shareholders in East Asia.” Washington, DC: World Bank. Manuscript. Coase, Ronald. 1961. "The Problem of Social Cost.” Journal of Law and Economics 3, 1-44. Coffee, John C. Jr. 1999. "The Future as History: The Prospects for Global Convergence in Corporate Governance and its Implications." Northwestern Law Review 93, 631-707. David, Rene, and John Brierley. 1985. Major Legal Systems in the World Today. London: Stevens and Sons.

Demirguc-Kunt, Asli, and Vojislav Maksimovic. 1998. "Law, Finance, and Firm Growth.” Journal of Finance 53, 2107-2139.

Easterbrook, Frank, and Daniel Fischel. 1991. The Economic Structure of Corporate Law. Cambridge, Mass: Harvard University Press. Edwards, Jeremy, and Klaus Fischer. 1994. Banks, Finance and Investment in West Germany Since 1970. Cambridge, U.K.: Cambridge University Press.

European Corporate Governance Network (ECGN). 1997. The Separation of Ownership and Control: A Survey of 7 European Countries Preliminary Report to the European Commission. Volumes 1-4. Brussels: European Corporate Governance Network.

Finer, Samuel. 1997. The History of Government, Vol. III. Cambridge, U.K.: Cambridge University Press.

Gerschenkron, Alexander. 1962. Economic Backwardness in Historical Perspective. Cambridge, Mass.: Belknap Press of Harvard University Press. 
Gorton, Gary, and Frank Schmid. 1999. "Universal Banking and the Performance of German Firms.” Philadelphia: University of Pennsylvania. Manuscript.

Grossman, Sanford, and Oliver Hart. 1988. "One-share-one-vote and the Market for Corporate Control." Journal of Financial Economics 20, 175-202.

Harris, Milton, and Artur Raviv. 1988. "Corporate Governance: Voting Rights and Majority Rules.” Journal of Financial Economics 20, 203-36.

Hart, Oliver. 1995. Firms, Contracts, and Financial Structure. London: Oxford University Press.

—. 1999. "Different Approaches to Bankruptcy." Cambridge, Mass: Harvard University. Manuscript.

Hellwig, Martin. 1999. "On the Economics and Politics of Corporate Finance and Corporate Control." University of Mannheim. Manuscript.

Henry, Peter Blair. 2000. “Do Stock Market Liberalizations Cause Investment Booms?” Journal of Financial Economics.

Hoshi, Takeo, Anil Kashyap, and David Scharfstein. 1991. "Corporate Structure, Liquidity, and Investment: Evidence from Japanese Industrial Groups.” Quarterly Journal of Economics $106,33-60$.

Hirschman, Albert. 1963. Journeys Toward Progress. New York: The Twentieth Century Fund. Jensen, Michael. 1989. "Eclipse of the Modern Corporation," Harvard Business Review 67, 6174.

Jensen, Michael, and William Meckling. 1976. "Theory of the firm: Managerial behavior, agency costs, and ownership structure." Journal of Financial Economics 3, 305-60.

Johnson, Simon. 1999. "Does Investor Protection Matter? Evidence from Germany's Neuer 
Markt." Cambridge, Mass: MIT. Manuscript.

Johnson, Simon, and Andrei Shleifer. 1999. "Coase v. The Coasians: the Regulation and Development of Securities Markets in Poland and the Czech Republic." Cambridge, Mass: MIT. Manuscript.

Johnson, Simon, Peter Boone, Alasdair Breach, and Eric Friedman. 1999. "Corporate Governance in the Asian Financial Crisis, 1997-98." Cambridge, Mass: MIT. Manuscript. Kang, Jun-Koo, and René M. Stulz. 1998. "Do Banking Shocks Affect Borrowing Firm Performance? An Analysis of the Japanese Experience.” Columbus: Ohio State University. Manuscript.

Keynes, J. 1931. “An Economic Analysis of Unemployment.” In Collected Writings. Volume XII. London: Macmillan.

King, Robert, and Ross Levine. 1993. "Finance and Growth: Schumpeter Might be Right." Quarterly Journal of Economics 108, 717-38.

La Porta, Rafael, Florencio Lopez-de-Silanes, and Andrei Shleifer. 1999. "Corporate Ownership around the World." Journal of Finance 54, 471-517.

La Porta, Rafael, Florencio Lopez-de-Silanes, Andrei Shleifer, and Robert W. Vishny. 1997. "Legal determinants of external finance." Journal of Finance 52, 1131-1150.

—. 1998. "Law and Finance.” Journal of Political Economy 106, 1113-55.

—. 1999. "The Quality of Government." Journal of Law, Economics and Organization 15, 222-279.

—. 1999b. "Investor Protection and Corporate Valuation." Cambridge, Mass: Harvard University. Manuscript. 
— 2000. "Agency Problems and Dividend Policies around the World." Journal of Finance.

Levine, Ross, and Sara Zervos. 1998. "Stock Markets, Banks and Economic Growth.” American Economic Review 88, 537-58.

Levine, Ross, Norman Loayza, and Thorsten Beck, 1999, "Financial Intermediary Development and Economic Growth: Causality and Causes," Journal of Monetary Economics, forthcoming.

Mayer, Colin. 1988. "New Issues in Corporate Finance." European Economic Review 32, 116788.

McCraw, Thomas K. 1984. Prophets of Regulation. Cambridge, Mass: The Belknap Press of Harvard University Press.

Modigliani, Franco, and Merton Miller. 1958. "The Cost of Capital, Corporation Finance, and the Theory of Investment." American Economic Review 48, 261-97.

Modigliani, Franco, and Enrico Perotti. 1998. "Security versus Bank Finance: the Importance of a Proper Enforcement of Legal Rules." Cambridge, Mass: MIT. Manuscript.

Morck, Randall, and Masao Nakamura. 1999. "Banks and Corporate Control in Japan.” Journal of Finance 54, 319-340.

Morck, Randall, Bernard Yeung, and Wayne Yu. 2000. “The Information Content of Stock Markets: Why Do Emerging Markets Have Synchronous Price Movements?" Journal of Financial Economics.

Myers, Stewart. 1977. "Determinants of Corporate Borrowing." Journal of Financial Economics $5,147-175$.

Nenova, Tatiana. 1999. "The value of a corporate vote and private benefits: a cross-country 
analysis." Cambridge, Mass: Harvard University. Manuscript.

Pistor, Katarina. 1999. "Law as a Determinant of Equity Market Development.” Cambridge, Mass: Harvard University. Manuscript.

Porter, Michael. 1992. “Capital Disadvantage: America’s falling capital investment system.” Harvard Business Review 46, 65-72.

Rajan, Raghuram, and Luigi Zingales. 1998. "Financial dependence and growth." American Economic Review 88, 559-586.

—. 1999. "The Politics of Financial Development.” University of Chicago. Manuscript.

Ramseyer, Mark, and Minoru Nakazato. 1999. Japanese Law: an Economic Approach. Chicago: University of Chicago Press.

Sapienza, Paola. 1999. “The Effects of Bank Mergers on Loan Contracts.” Chicago: Northwestern University. Manuscript.

Shleifer, Andrei, and Daniel Treisman. 1999. Without a Map. Cambridge, MA: MIT Press.

Shleifer, Andrei, and Robert W. Vishny. 1997. “A Survey of Corporate Governance.” Journal of Finance 52, 737-783.

Stigler, George. 1964. "Public Regulation of the Securities Market." Journal of Business 37,117142.

Stulz, René M. 1999. “International Portfolio Flows and Securities Markets.” Working Paper 993, Fisher College of Business, The Ohio State University. Columbus, Ohio.

Weinstein, David, and Yishay Yafeh. 1998. "On the Costs of a Bank-Centered Financial System: Evidence from the Main Bank Relations in Japan.” Journal of Finance 53, 635-672. Wolfenzon, Daniel. 1999. “A Theory of Pyramidal Structures.” Cambridge, Mass: Harvard 
University. Manuscript.

Wurgler, Jeffrey. 2000. "Financial Markets and the Allocation of Capital.”Journal of Financial Economics.

Zingales, Luigi. 1994. "The Value of the Voting Right: a Study of the Milan Stock Exchange.” The Review of Financial Studies 7, 125-148.

—. 1995. "Inside Ownership and the Decision to Go Public." Review of Economic Studies 62, 425-448. 
Table 1

\section{Legal origin and investors rights}

This table presents data on measures of investor protection for 49 countries classified by their legal origin. The source of the data is La Porta et al. (1998). Panel A shows the measures of shareholder protection across legal origins. The "antidirector rights index" is a summary measure of shareholder protection. This index ranges from 0 to 6 and it is formed by adding 1 when: the country allows shareholders to mail their proxy vote to the firm; shareholders are not required to deposit their shares prior to the General Shareholders' Meeting; cumulative voting or proportional representation of minorities in the board of directors is allowed; an oppressed minorities mechanism is in place; the minimum percentage of share capital that entitles a shareholder to call for an Extraordinary Shareholders' Meeting is less than or equal to 10 percent (the sample median); or shareholders have preemptive rights that can only be waved by a shareholders' vote. The rest of the rows in Panel A show the percentage of countries within each legal origin for which each component of the "antidirector rights index" is provided by the law. Panel B shows the measures of creditor protection across legal origins. The "creditor rights index" is a summary measure of creditor protection. This index ranges from 0 to 4 and is formed by adding 1 when: the country imposes restrictions, such as creditors' consent or minimum dividends to file for reorganization; secured creditors are able to gain possession of their security once the reorganization petition has been approved (no automatic stay); secured creditors are ranked first in the distribution of the proceeds that result from the disposition of the assets of a bankrupt firm; and the debtor does not retain the administration of its property pending the resolution of the reorganization. The rest of the rows in Panel B show the percentage of countries within each legal origin for which each component of the "creditor rights index" is provided by the law. Panel C shows measures of legal enforcement. "Efficiency of the judicial system" is an index ranging from 0 to 10 representing the average of investors' assessments of conditions of the judicial system in each country between 1980-1983 (lower scores represent lower efficiency levels). "Corruption" is an index ranging from 0 to 10 representing the average of investor's assessments of corruption in government in each country between 1982-995 (lower scores represent higher corruption). "Accounting standards" is an index created by examining and rating companies' 1990 annual reports on their inclusion or omission of 90 items falling in the categories of general information, income statements, balance sheets, funds flow statement, accounting standards, stock data and special items.

\section{Legal Origin}

\begin{tabular}{cccccc} 
& Common & French Civil & German & Scandinavian & World \\
Variables & Law & Law & Civil Law & Civil Law & Average \\
& $(18$ countries $)$ & $(21$ countries $)$ & $(6$ countries $)$ & $(4$ countries $)$ & $(49$ countries $)$ \\
\hline
\end{tabular}

Panel A: Measures of Shareholder Protection

Antidirector rights index

Proxy by mail

Shares not blocked before meeting

Cumulative voting / proportional

represent'n

Oppressed minority

Preemptive right to new issues

$\%$ Share of capital to call and ESM $\leq 10 \%$

Creditor rights index

No automatic stay on secured assets

Secured creditors first paid

Restrictions for going into reorganization

Management does not stay in reorganization

Efficiency of the judicial system

Corruption

Accounting standards
4.00

$39 \%$

$100 \%$

$28 \%$

$94 \%$

$44 \%$

$94 \%$

3.11

$72 \%$

$89 \%$

$72 \%$

$78 \%$
2.33

$5 \%$

$57 \%$

$29 \%$

$29 \%$

$62 \%$

$52 \%$

Panel B:
2.33

$0 \%$

$17 \%$

$33 \%$

$50 \%$

$33 \%$

$0 \%$
2.33

$67 \%$

$26 \%$

$65 \%$

$42 \%$

$26 \%$

Panel C: Measures of Enforcement

$0 \%$
5.84

51.17
8.54

8.03

$100 \%$

$33 \%$

$33 \%$

62.67
3.00

$25 \%$

$100 \%$

$0 \%$

$0 \%$

$75 \%$

$0 \%$

$18 \%$

$71 \%$

$27 \%$

$53 \%$

$53 \%$

$78 \%$

10.00 


\section{Legal Origin}

Variables

$\begin{array}{cc}\text { Common } & \text { French Civil } \\ \text { Law } & \text { Law }\end{array}$

(18 countries)

\section{German} Civil Law (6 countries)
Scandinavian

Civil Law

(4 countries)
World

Average

(49 countries) 